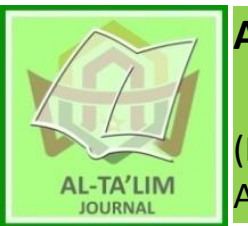

AL-TA'LIM JOURNAL, 25 (3), 2018, (199-205)

(Print ISSN 1410-7546 Online ISSN 2355-7893)

Available online at http://journal.tarbiyahiainib.ac.id/index.php/attalim

\title{
As You Write, It Helps You Listen: An Experiment in TOEFL Preparation Class
}

\author{
Received: $30^{\text {th }}$ July 2018; Revised: $04^{\text {th }}$ September 2018; Accepted: $26^{\text {th }}$ November 2018 \\ Permalink/DOI: http://dx.doi.org/10.15548/jt.v25i3.483
}

\section{Nyak Mutia Ismail *) \\ Universitas Syiah Kuala, Banda Aceh, Indonesia \\ E-mail: nyakmutiaismail2010@gmail.com}

\section{Fera Busfina Zalha}

University of Leeds, United Kingdom

E-mail: $\underline{\text { fera@gmail.com }}$

*) Corresponding Author

\begin{abstract}
This study aims to test whether using the technique named keeping-journals during the TOEFL preparation class is beneficial for the listening section part A of the test. The quantitative pretest-posttest method used in this study involves single-group design consisting of 36 fifth semester college students at Syiah Kuala University, Aceh, Indonesia. The result is considered essential since, practically, TOEFL tutors need to bring TOEFL learners to keep track on their learning rate on their own; hopefully, the result can best suit the theoretical gap since there have been only few experimental studies conducted on Listening Section of TOEFL through journal-keeping. The findings approved that the $H_{a}$ is accepted for the $t_{\text {value }}$ is 1.90 ( $d f 34$, $\alpha=0.05,-2.02 \leq t \geq 2.02)$. It is also significant for the $\operatorname{sig}_{\text {value }}$

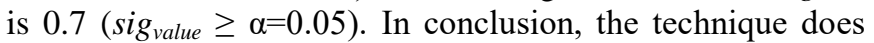
help the learners in tackling problems they face in Listening section on TOEFL part $\mathrm{A}$ as it enhances their listening performance, attitude, and motivation.
\end{abstract}

Keywords: Keeping-journal; Listening; TOEFL test; language test; self-monitoring.

How to cite: Ismail, N., \& Zalha, F. (2018). As you write, it helps you listen: an experiment in TOEFL preparation class. Al-Ta Lim Journal, 25(3). doi:http://dx.doi.org/10.15548/jt.v25i3.483

\section{INTRODUCTION}

Test of English as a Foreign Language, known as TOEFL, is considered as a highstake testing by most Indonesian students (Bejar, Douglas, Jamieson, Nissan, \& Turner, 2000; Cumming, Kantor, Powers, Santos, \& Taylor, 2000; Enright et al., 2000; Jamieson, Jones, Kirsch, Mosenthal, \& Taylor, 2000; Phillips, 2001). Basically, this test seeks the test-takers' ability in both knowledge and performance as a whole proficiency demanded in English language. It is a basic indicator tomeasurewhetherthey are able to employ English as a means of communication in divergent situations. Since the world's civilization has become more and more globalized, English absolutelyappears as th elingua-franca among mankind and it covers the majority of academic deliverance. Based on this fact, most universities in our homeland-Indonesia-as well as abroad, standardizes a certain TOEFL score as an obligatory requirement either for the admission or for the graduation (Ananda, 2016; Cushing Weigle, 2010; Mahmud, 2014). It is highly intended that all scholars can skip this hurdle without problems so that they have smoother access to the knowledge in their specialty or to meet their job qualification later when they graduate.

There are three types offered in this test which are paper-based test, computerbased test, and internet-based test. Paperbased test basically offers three sections 
which are listening, structure and written expression, and reading. To a certain circumstance, the Test of Written English (TWE) are also administered but it is rarely found in Indonesia, especially in Aceh. The computer-based and the internet-based test are normally more complex as all of language skills (speaking, listening, reading, and writing) are required in the instruction of these two tests; in addition, the integrated instructional models are also parts of IBT and CBT TOEFL tests. To go further, it can be concluded that even in TOEFL test alone, there are several different tests with various instructions and scoring systems. With regard to the various types of the tests along with their complexity, obviously, a test-taker should be advanced enough in order to be able to face all of these test types, readily.

Regardless the importance of the test, the reality in life indicates a very contrary situation. Based on the authors' observation, most TOEFL preparation classes only set "item discussion" as their teaching strategy, meaning that the tutor only discusses the items one by one. This situation ends up with opacity to the learners as they are not aware of the starting points and the hallmarks in the discussion. Apparently, there is a technique worth applying in TOEFL preparation class. Looking at the fact that most Acehnese TOEFL students are less proficient, activating their metacognitive awareness by monitoring their own progress during the learning process is very illuminating (Chiu, Liou, \& Yeh, 2007; Son, 2007; Thomas \& Reinders, 2010; Yang \& Chen, 2007). Chang (2007) supports that self-monitoring strategies influence lessproficient learners greater than high-proficient ones. Not much to our surprise, it is presumably because bright students are better in keeping track and regulating their own knowledge as well as employing the tricks and strategies in facing problems (AmatoZech, Hoff, \& Doepke, 2006; Cheng, 2008; Jitendra, Kay Hoppes, \& Xin, 2000; Sinclair, 2006). Based on this fact, self-monitoring strategy is considered more beneficial for less proficient students and it can meet their needs.
In this study, the technique named Keeping-Journal was tested to see whether or not this strategy can increase students' score in TOEFL listening. This techniques has been seen as a self-monitoring aid in learning and it automatically wakes the metacognitive awareness that the learners' possess. In its essence, Self-Monitored Learning strategy, which can be accomplished through journalkeeping, is a strategy aiming at assisting learners to develop and control their abilities, encompassing academic, behavioral and social ability (Bell, Magill, Carter, \& Lane, 2013; de Bruin \& van Gog, 2012). Numerous positive impacts are achieved from the good implementation of this strategy, namely the growing academic zone which leads to better improvement in cognitive ability, developed behaviors which are the increase of motivation, and social interaction between mates as well as teachers (Nicol \& Macfarlane-Dick, 2006; Taras, 2003). (Prichard, Stratford, \& Bizo, 2006). Rao, Collins, \& DiCarlo (2002) further affirms that keeping journal not only enhances students' academic skills but also improves their social growth as a developing human.

A study by Mynard (2008) was conducted to 22 Japanese students who were studying in England. Therespondentswere expected to write on electronic journal (blogs) for 12 weeks. From the study, it is known that the students used their blogs to share problems they faced during their time studying in the UK. Therefore in its turn, this study finds that self-reflection, which was done by using the journal-keeping technique, is a good alternative used by the students to monitor their strength and weakness. In line with (Gay \& Kirkland, 2003; Grant, Franklin, \& Langford, 2002; Shaarawy, 2014; Takano \& Tanno, 2009) to 16 students in Egypt also earns a result declaring that the journalwriting increased students' ability in critical thinking - as it is known that critical thinking is a process of regulating knowledge which is directly tied to metacognitive strategy. Finally, Chang (2007) has also experimented self-monitoring to 99 college students in Taiwan and the result was likely to the fact 
that through the implementation of the strategy, the students advanced in their academic performances and motivational beliefs.

To be more precise, the scope of this study was only to see whether the JournalKeeping technique works well in increasing students' score in TOEFL Listening Part A. This study is consideredsignificant since it is seen as a contribution to the theoretical basis that there are lack of studies on implementing Journal-Keeping in TOEFL Listening section, and it is expected that the result can fill the gap. Practically, it is good for TOEFL tutors to modify their teaching techniques rather than continue on using monotonous techniques.

Shortly, from the elaboration above, a two-tailed hypothesis was formulated to be tested. It is as follows, "Does journal-keeping increase the experimental group's mean score?".

\section{METHOD}

This study utilized quantitative approach as its research method. Specifically, a quasi-experimental study was carried out with pretest-posttest design to a single-group design. The data was collected through pretest and post-test at the beginning and at the end of the treatment. The comparison of these two tests' results are shown in the following section; and the experimentation phases were repeatedly conducted for seven weeks for the experimental group.

The participants of this study were 36 students who are the fifth semester Pharmaceutical students at Syiah Kuala University, Aceh, Indonesia. The instrument used was pre-test and post-test. Both of the tests provide 30 TOEFL questions on Listening Section part which were taken from Sharpe (2001) the test items administered for both pre-test and post-test are completely different. Furthermore, the data obtained from both of the tests was examined for its normality, homogeneity, mean score, and standard deviation. Finally, the $t_{\text {value }}$ of the data was calculated in attempt to test the hypothesis.

\section{RESULT AND DISCUSSION}

The preconditions that should be met in order to prove hypothesis through t-test are normality, homogeneity, and mean score. The data distributions from both tests are normal (kolmogorov-smirnov value $0.607 \geq \alpha=0.05$ ). This indicates that there are no outlier data. All of the data are considered homogeneous since $F_{\text {value }} \geq \alpha=0.05$. Lastly, after the implementation of journal-keeping strategy during the TOEFL preparation for Listening Section part A, the mean score increased from 62.43 to 72.65 , implying that the strategy bring positive effect. Therefore, the data analysis was preceded and below is the result of the hypothesis testing. In the following table, HypothesisTesting assemblies the pretest and post-test of the treated group.

Table 1. Hypothesis Testings

\begin{tabular}{ccccc}
\hline Tests & $\mathrm{t}_{\text {value }}$ & $\mathrm{Sig}_{\text {value }}$ & $\mathrm{H}_{\mathrm{a}}$ & $\mathrm{H}_{\mathrm{o}}$ \\
\hline Pre-Post & 1.90 & 0.7 & $\sqrt{ }$ & $\mathrm{X}$ \\
\hline
\end{tabular}

From the table above, it shows that in pre-post testing, which is the t-test between pretest mean score and post-test mean score, the $t_{\text {value }}$ is 1.90 ; since $t_{\text {table }}$ for $d f 68$ (twotailed) is within -2.02 and 2.02. Thus, the $t_{\text {value }}$ is still under the critical area and $\mathrm{H}_{\mathrm{a}}$ is accepted. To see whether or not it is significant, the $\operatorname{sig}_{\text {value }}$ is also provided in the table which shows that the value is 0.7 . Since the value is considered significant if $\operatorname{sig}_{\text {value }} \geq$ $\alpha=0.05$, hence, it can be concluded that the score increase is statistically significant. The $\mathrm{H}_{\mathrm{a}}$ is again accepted.

Concerning the increase that is gained from the experimental group, which was exposed to Journal-Keeping, below are several discussions. First of all, by doing journal-keeping, the learners start to be aware of their own strength and weakness. At the beginning, the students relatively tended to see their weak points, however, after three weeks and more, they became able to understand their weakness and tried to arrange 
strategy on how to overcome the weakness. This is much to the author's surprise as quoted from some of the students journal below. The journals are basically written in Bahasa Indonesia but have been translated into English for the reasons of efficiency. $S$ stands for Student.

Week 1:

\section{S1: (This) Listening class is so stressful.}

Week 3:

S1: I am absolutely happy and delighted because I have got some knowledge from this course...

Based on the comment above, it can be predicted that in Week 1, the student had a negative impression towards the atmosphere of TOEFL class, especially listening class since he said that the class was stressful. Meanwhile, in week 3, he found the tricks in answering Listening TOEFL part $\mathrm{A}$ and his comment became more positive. The tricks were generally taught, and this student used the journal to keep track about what has been learned although he did not list the trickssome of which would likely be forgotten, if so. However, one thing is clear here, he has successfully built the metacognitive awareness by being aware of his positive attitude toward the Listening TOEFL class. This strategy has helped the student through explicit strategy instruction Chamot (2004) which means the strengthening phase of the learning process-he did get it mapped. Indeed, through implicit instruction, all students may be able to understand what they have learnt but most of the materials would only be taken into short-term memory processing; whereas the explicit one reinforces the understanding as it is written and saved in more arranged "memory files". Then, a comment by a student in her journal is also provided below, and her notion is apparently surprising.

\section{Week 2}

S2: I think I can never understand because the speakers speak too fast and (with) accent.

\section{Week 5}

S2: I can understand all of the subjects, but a little hard for me to translate vocabulary. But in my opinion, the subject about "Suggestions" and "Passives" are awesome. But I want game.

In the comment above, the student showed that her attitude and opinions about Listening TOEFL had changed only in 3 weeks. As a point of information, this student got 68 in her pretest and fluctuated it sharply into 96 in her post-test. The authors see this as the impact of both the teaching technique which is surely intervening, and the student's motivational belief that is built during the journal-writing process where the student needed to reflect and manage knowledge as mentioned by Chang (2007). The point that comes further into the consideration is that she wrote "But I want game" indicating that for her the class was presumably boring; she wanted something more challenging. Concerning to this notion, as mentioned earlier, the Journal-Keeping, which is a strategy used in Self-Monitoring learning model, serves poor students better. Unfortunately, it is moderately not an interesting technique for bright students. Thus, it comes to conclusion that this student is one of the bright ones with poor motivation. Once she got back the motivation, she could incline her score.

Further, in the following are more students' comments. Initially, the constant behavior toward the class, but better academic improvement in the following comment is shown below.

Week 1

S3: The class is good.

Week 4

S3: I get an increased value in my practice, I am so happy. It is a good day for me. I will review the tricks again at home.

The comment above implies that in Week 1, this student might sound pessimistic 
and felt plain - indeed with a positive wordchoice in her comment-about the class. Contrarily, in Week 4, she showed her ecstatic feelings through more elaborated expressions confidently, which is a great surplus of positive attitude change. Hiemstra (2001) justifies that journals also help students trust their intuition and make them more confident in self-expression. Additionally, we can see that the ability to self-monitor has been turned on and it is definitely beneficial as urge that students who are skillful also own high ability in selfmonitoring (Boud, 2001; Connor-Greene, 2000; Spalding, Wilson, \& Mewborn, 2002).

More comments from another student is available below.

\section{Week 1}

S4: Nothing is different. It is an English course. Only with a different lecturer.

Week 6:

S4: I learn a lot today and I can answer more questions correctly. Unlike previous weeks, I kept on losing my concentration. But not today.

The point that directly catches our attention when we see the comment above is that this student had plain feelings toward English, especially listening. Somehow, she reshaped her attitudes after six weeks. In addition, it seems that she is a person who is easily distracted when she mentioned about "losing concentration". So, it can be assumed that although she succeeded in this listening class, she might lose track again. So that, for this kind of student, longer time is needed for the habituation to make them remain on track.

Lastly presented in this study, below is the comment from a student with high motivation but poor performance.

\section{Week 1:}

S5: I like English but Listening is hard because it is too fast to listen clearly.
Week 3:

S5: Today is very fun because I learn a lot of knowledge I did not have before. Now I have tricks in answering Listening.

Week 7:

Like previous weeks, I get more and more tricks. Now I changed my mind, it is not that hard.

The student was convinced that she was growing her ability in Listening after the technique implementation and it is more than satisfactory news for a student with lower proficiency but higher motivation. This strategy has really helped her.

From the elaborations of findings and discussions above, it is worth to say that the alternate hypothesis is granted and the Journal-Keeping strategy benefits the students listening skills as well as nurtures their motivation and attitude toward Listening TOEFL. However, like all other teaching techniques, the journal-keeping technique also has weaknessess in learning. During writing journals, students learn how to judge but they can over-evaluate their own performance and therefore the claim could be profoundly subjective (Chan, 2010).

\section{CONCLUSION RECOMMENDATION}

AND

Briefly, this study may have offered broader perspectives on the strategies and techniques used in teaching TOEFL. The implementation of the Journal-Keeping strategy in TOEFL preparation class can enhance the students' ability in the Listening section Part A. Beside this strategy increases the students' performance as it can be seen in their pretest-posttest score comparison; it also promotes motivational growth for some students who have assumed that TOEFL Listening is difficult to learn. Additionally, this technique which is based on selfmonitoring strategy has changed the students' perspectives that dislike English to have better attitude toward it. Finally, it is recommended that TOEFL tutors utilized this 
technique in helping them with TOEFL preparation, particularly for weak students.

\section{REFERENCES}

Amato-Zech, N. A., Hoff, K. E., \& Doepke, K. J. (2006). Increasing on-task behavior in the classroom: Extension of self-monitoring strategies. Psychology in the Schools, 43(2), 211-221.

Ananda, R. (2016). Problems with section two ITP TOEFL test. Studies in English Language and Education, 3(1), 35-49.

Bejar, I., Douglas, D., Jamieson, J., Nissan, S., \& Turner, J. (2000). TOEFL 2000 listening framework. Princeton, NJ: Educational Testing Service.

Bell, L., Magill, L., Carter, E. W., \& Lane, K. L. (2013). Self-Monitoring Equipping Students to Manage Their Own Behavior in the Classroom. Tennessee Vanderbilt University: Department of Education.

Boud, D. (2001). Using journal writing to enhance reflective practice. New Directions for Adult and Continuing Education, 2001(90), 9-18.

Chamot, A. U. (2004). Issues in language learning strategy research and teaching. Electronic Journal of Foreign Language Teaching, 1(1), 14-26.

Chan, C. (2010). Assessment: Self and peer assessment, assessment resources. Available at HKU University of Hong Kong

Chang, M.-M. (2007). Enhancing web-based language learning through selfmonitoring. Journal of Computer Assisted Learning, 23(3), 187-196.

Cheng, L. (2008). Washback, impact and consequences. In Encyclopedia of language and education (pp. 24792494). Springer.

Chiu, T.-L., Liou, H.-C., \& Yeh, Y. (2007). A study of web-based oral activities enhanced by automatic speech recognition for EFL college learning. Computer Assisted Language Learning, 20(3), 209-233.

Connor-Greene, P. A. (2000). Making connections: Evaluating the effectiveness of journal writing in enhancing student learning. Teaching of Psychology, 27(1), 44-46.

Cumming, A., Kantor, R., Powers, D., Santos, T., \& Taylor, C. (2000). TOEFL 2000 writing framework. In TOEFL-MS-18. Educational Testing Service Princeton, NJ.

Cushing Weigle, S. (2010). Validation of automated scores of TOEFL IBT tasks against non-test indicators of writing ability. Language Testing, 27(3), 335353.

de Bruin, A. B., \& van Gog, T. (2012). Improving self-monitoring and selfregulation: From cognitive psychology to the classroom. Elsevier.

Enright, M., Grabe, W., Koda, K., Mosenthal, P., Mulcahy-Ernt, P., \& Schedl, M. (2000). TOEFL 2000 reading framework. Educational Testing Service Princeton, NJ.

Gay, G., \& Kirkland, K. (2003). Developing cultural critical consciousness and self-reflection in preserves teacher education. Theory into Practice, 42(3), 181-187.

Grant, A. M., Franklin, J., \& Langford, P. (2002). The self-reflection and insight scale: A new measure of private selfconsciousness. Social Behavior and Personality: An International Journal, 30(8), 821-835. 
Hiemstra, R. (2001). Uses and benefits of journal writing. New Directions for Adult and Continuing Education, 2001(90), 19.

Jamieson, J., Jones, S., Kirsch, I., Mosenthal, P., \& Taylor, C. (2000). TOEFL 2000 framework. Princeton, NJ: Educational Testing Service.

Jitendra, A. K., Kay Hoppes, M., \& Xin, Y. P. (2000). Enhancing main idea comprehension for students with learning problems: The role of a summarization strategy and selfmonitoring instruction. The Journal of Special Education, 34(3), 127-139.

Mahmud, M. (2014). The EFL students' problems in answering the Test of English as a Foreign Language (TOEFL): a study in Indonesian context. Theory and Practice in Language Studies, 4(12), 2581-2588.

Mynard, J. (2008). A blog as a tool for reflection for English language learners. The Philippine ESL Journal, 1(1), 77-90.

Nicol, D. J., \& Macfarlane-Dick, D. (2006). Formative assessment and selfregulated learning: A model and seven principles of good feedback practice. Studies in Higher Education, 31(2), 199-218.

Phillips, D. (2001). Longman complete course for the TOEFL test: Preparation for the computer and paper tests. Longman London.

Prichard, J. S., Stratford, R. J., \& Bizo, L. A. (2006). Team-skills training enhances collaborative learning. Learning and Instruction, 16(3), 256-265.

Rao, S. P., Collins, H. L., \& DiCarlo, S. E. (2002). Collaborative testing enhances student learning. Advances in Physiology Education, 26(1), 37-41.
Shaarawy, H. Y. (2014). The Effect of Journal Writing on Students' Cognitive Critical Thinking Skills:" A QuasiExperimental Research on an English as a Foreign Language (EFL) Undergraduate Classroom in Egypt". International Journal of Higher Education, 3(4), 120-128.

Sharpe, P. J. (2001). Barron's how to prepare for the TOEFL. Barron's Educational Series.

Sinclair, B. (2006). Independent Learning Schemes: A Practical Approach. D. Dixon, H. Baba, P. Cozen, M. Thomas (eds). Dubai, UAE: TESOL Arabia.

Son, J.-B. (2007). Learner experiences in web-based language learning. Computer Assisted Language Learning, 20(1), 21-36.

Spalding, E., Wilson, A., \& Mewborn, D. (2002). Demystifying reflection: A study of pedagogical strategies that encourage reflective journal writing. Teachers College Record, 104(7), 1393-1421.

Takano, K., \& Tanno, Y. (2009). Selfrumination, self-reflection, and depression: Self-rumination counteracts the adaptive effect of selfreflection. Behavior Research and Therapy, 47(3), 260-264.

Taras, M. (2003). To feedback or not to feedback in student self-assessment. Assessment \& Evaluation in Higher Education, 28(5), 549-565.

Thomas, M., \& Reinders, H. (2010). Taskbased language learning and teaching with technology. A\&C Black.

Yang, S. C., \& Chen, Y.-J. (2007). Technology-enhanced language learning: A case study. Computers in Human Behavior, 23(1), 860-879. 